\title{
Sustainable tourism: Gen z?
}

\author{
Caner Çalışkan
}

\section{ABSTRACT}

Keywords:

Tourism,

Sustainable Tourism, Gen Z

Article History:

Submitted: 13.11.2020

Accepted: 23.05 .2021
Tourism is a system that has social, environmental and economic impacts on a global scale. These impacts, which seem as a chronic problem especially in the balance of environment and economy, need to be evaluated from different perspectives. The concept "sustainable tourism" is an approach for overcoming problems associated with undesirable impacts. Economic gain, resource conservation and inter-and intra-generational equality are the core factors of this approach. Therefore, it is important to reinterpret it in terms of way to today's generation. This generation called Generation $Z$ (Gen $Z$ ), have quite different characteristics from previous generations. As natives of the digital world Gen Z'ers, born and growing in a period of economic crises, wars and environmental problems. This innovative generation has a strong communication network, uses technology extensively and easily accesses information. Therefore, it is a significant subject of investigation for the applicability of the concept of sustainable tourism. In this study, the diverging and adaptive aspects of sustainable tourism and Gen $Z$ are examined and various inferences have been made in the context of today's world.

Doi: https://doi.org/10.31822/jomat.2021-6-2-107

\section{Introduction}

Today's world is experiencing a depression due to the psychological, economic and environmental changes. This issue which characterized with the domination of the nature by human beings, stands at a critical crossroad (Kapecki, 2020; Özel, 2007). While this reality contains dramatic examples such as global warming, deforestation and desertification, it becomes more concrete with increasing consumption rates and social inequality levels (Weaver, 2006). At this point, sustainable development is an important concept in the triangle of environment, society and consumption (Çalışkan, 2017). The concept of sustainable development which expresses the success of social, economic and environmental goals (Koltun, 2010), on the other hand, has a controversial content that can be interpreted differently. It is seen that the concept, which includes different approaches regarding the meaning and depth of application, is ambiguous on the axis of socio-economy and environmental conflict (Giddings, Hopwood \& O'Brien, 2002). As a matter of fact, the anthropocentric structure of human beings and the balanced use of limited resources are the oxymoron of sustainable development (Higgins-Desbiolles, 2018). Depending on crazy-quilt (Rosenau, 1995) and anthropocentric nature of modern life, Gen Z is the key factor of sustainable development. Moreover, by 2030 , this generation will be the central workforce in society and will play a major role in creating a sustainable future and achieving sustainable development goals. In other words, Gen $\mathrm{Z}$ is an indispensable and strategic component of building sustainable future (Yamane \& Kaneko, 2021).

An important context of the concept of sustainable development and Gen $\mathrm{Z}$ is the phenomenon of tourism and the understanding of sustainable tourism. Sustainable tourism is a derivative of sustainable development (Sharpley, 2010) and is built on the similar principles (Garrod \& Fyall, 1998). Based on the motto of Brundtland Report "...meets the needs of the present without compromising the ability of future generations to meet their needs." (WCED, 1987: 43), the understanding of sustainable tourism also prioritizes the principle of intergenerational equality and emphasizes the fair distribution of 
benefits and costs (Liu, 2003). It should be noted that, tourism is one of the largest and fastest growing sectors in the world and has social, economic and environmental impacts on a global scale (Ap, 1992; Anderecek et al., 2005; Hall \& Lew, 2009). Apart from global effects, the emergence of new demand structures and the increasing rate of enterprise highlight the concept of sustainability (Lordkipanidze, Brezet \& Backman, 2005), and this indicates the perspective of intergenerational equality (McMinn, 1997).

Gen Z can be a critical question mark for sustainable tourism, which has priorities such as respect for the local culture and socio-economic benefit beside the principle of environmental conservation (Haddouche \& Salomone, 2018). Low sense of belonging, being individualistic (Taş, Demirdöğmez, \& Küçükoğlu, 2017) and growing up in a complex, changeable and chaotic period make Gen Z an important research topic for tourism, which is deeply affected by demographic changes (Robinson \& Schänzel, 2019). From this point of view, this study examines the foci of the concepts of sustainable tourism and Gen $\mathrm{Z}$ and analyzes the contrasting and conflicting aspects of the two concepts. In this context, the future emphasis of the sustainable tourism is reinterpreted on the basis of today's world and suggestions are presented.

\section{Moving Towards Society $\mathbf{5 . 0}$}

According to the philosophy of Society 5.0, which was first emphasised by the Government of Japan, it depicts the construction of super-smart societies while also expressing an understanding that shapes the future and constantly generates new values and services (Government of Japan, 2016).

The world has witnessed different social transformations in the historical process. These transformations of human beings, the historical process can be summarized as follows: First, Society 1.0 (Hunting and coexistence with nature); Second, Society 2.0 (agricultural cultivation, increasing organizations and nation-building); Society 3.0 (industrialization and mass production); Society 4.0 (information society) and Society 5.0 (Prosperous humancentered society built upon Society 4.0) (Harayama, 2017:10). In Society 5.0, it is essential to seek a common solution to global challenges, regardless of any region, gender or age. Here, each of economic and technological activities are necessary for the wellbeing of the whole societies, not a particular minority (See, Government of Japan, 2016; Fukuyama, 2018). It should be noted that,
Sustainable Development Goals (SDGs) constitute the basis of this understanding (Roblek, et al., 2020; Arı, 2021). Understanding of Society 5.0 focuses on technologic innovations to reduce the global risks such as ageing of population, natural disasters, inequalities and security problems (Pereira, Lima \& Charrua-Santos, 2020). In this sense, considering the impact of tourism on society and the environment, global restrictions are inevitable, on the other hand, existing tourism activities must be sustained. At this point, the concept of Society 5.0 refers to the building of a smart society with a high level of awareness, which points to international harmony and technologyoriented sustainable practices (Hysa, Karasek \& Zdonek, 2021). Based on this, it can be argued that Gen $\mathrm{Z}$ is a strategic variable of the mentioned technological developments and social transformation (See Keskin, 2018).

\section{Gen Z}

As broadly known, the concept of generation can be defined as: "identifiable group that shares birth years, age location, and significant life events at critical developmental stages" (Kupperschmidt, 2000: 66). The notion of generation can be thought of as a kindredship referring to different levels in a common family tree. This concept serves a fundamental function in defining kinship relationships such as parents, grandparents, children, grandchildren. It is also necessary to systematically examine issues such as family systems, ethnographic studies and residential practicec (Alwin \& McCammon, 2007). Accordingly, this concept is a characteristic that differs and transforms in the historical process. Generational separation based on cultural differences, historical events and social changes is the subject of research in a wide range of fields from sociology to psychology. In this context, generation classification is as follows: (1) Traditionalists (2) Silent Generation (3) Baby Boomer (4) X (5) Y and (6) Z Generation (Adıgüzel, Batur \& Ekşili, 2014). In addition, as it is expected, while different results were obtained from previous studies on generations conducted in different time periods, these studies show that both similarities and differences exist among all these groups (Anantatmula \& Shrivastav, 2012).

Considering today's realities, generational distinctions should be made according to sociological facts, rather than biological parameters (Keleş, 2011). In the new world order, "Digital" age began with the technological revolution. This era, which is a reflection of the 
radical transformations started with the industrial revolution, is a sociological reality that has led to the formation of new business models and systems and the development of new communication techniques. Nowadays, today's generation has easy access to unlimited information, adapts easily to rapid change, and adopts new lifestyles (Yalçın Kayıkçı \& Kutluk Bozkurt, 2018). Therefore, the concept of "Gen Z" refers to a new sociological distinction based on information, technology, internet and social networks (Haddouche \& Salomone, 2018). Gen Z'ers witness to a sequence of events such as political events (elections, protests, etc.); natural disasters / environmental crises (climate change, tsunami, etc.); social movements (refugee crises etc.), war and terrorism (9/11 Attacks, trade wars, etc.). These global events influenced on Gen Z'ers' feelings of collective consciousness and led to human values such as universalism, benevolence, self-direction, achievement and security (Sakdiyakorn, Golubovskaya \& Solnet, 2021). In this context, the structural features of Gen $\mathrm{Z}$ are described in Table 1.

Table 1. Gen Z: Distinctive Features

\begin{tabular}{|c|c|}
\hline Author(s) & Distinctive Features \\
\hline $\begin{array}{l}\text { Gabrielova and Buchko } \\
\text { (2021) }\end{array}$ & $\begin{array}{l}\text { They are socially, emotionally and intellectually sensitive due to being raised by protectionist parents. This has } \\
\text { made it difficult for them to become autonomous adults who can overcome life's difficulties. In addition, they } \\
\text { may not want to take responsibility and take precautions in the face of difficult situations. }\end{array}$ \\
\hline Seibert (2021) & $\begin{array}{l}\text { They are successful in accessing information and communicating in the digital world. Similarly, they are } \\
\text { productive consumers of digital technology. }\end{array}$ \\
\hline $\begin{array}{l}\text { Priporas, Stylos and } \\
\text { Kamenidou }(2020)\end{array}$ & $\begin{array}{l}\text { They are well educated, technologically equipped, innovative and creative. Gen } Z \text {, expressed as natives of the } \\
\text { digital world, are individualistic, pragmatic, open-minded and sensitive to social issues. }\end{array}$ \\
\hline Hoxha and Zeqiraj (2020) & $\begin{array}{l}\text { Gen Z'ers are concerned with financial literacy and savings. They care creativity, uniqueness and authenticity. } \\
\text { However flexibility, authenticity, choice, convenience and integration are important factors that characterize } \\
\text { their lifestyle patterns. }\end{array}$ \\
\hline $\begin{array}{l}\text { Klopotan, Aleksić and } \\
\text { Vinković (2020) }\end{array}$ & Gen Z'ers' ethical behavior is influenced by personal beliefs rather than general rules and procedures. \\
\hline Subawa et al. (2020) & $\begin{array}{l}\text { Information technology is part of their lives. They were born in an era where internet use and access to } \\
\text { information have become a culture. Therefore, this culture has an influence on their values, ideas and goals. }\end{array}$ \\
\hline Chillakuri (2020) & $\begin{array}{l}\text { Gen Z'ers are entrepreneurial, result-oriented, tech-savvy, ambitious, high on self-learning, self-directed, } \\
\text { independent of their families, self-confident and autonomous. }\end{array}$ \\
\hline 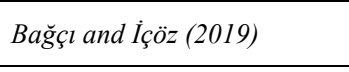 & $\begin{array}{l}\text { It is a generation that uses technology intensively, socializes through the internet and constantly interacts with } \\
\text { mobile technologies. }\end{array}$ \\
\hline $\begin{array}{l}\text { Chicca and Shellenbarger } \\
\text { (2018) }\end{array}$ & $\begin{array}{l}\text { They are in constant interaction in a digital world. Social relationship skills are not sufficiently developed due } \\
\text { to intensive use of technology and isolation. This situation has made them at risk for psychological problems } \\
\text { such as anxiety and depression. The pragmatic Gen Z'ers are open to different ideas but generally do not take } \\
\text { an active role in social issues. Instead, they prefer passive activism. }\end{array}$ \\
\hline Ince and Bozyiğit (2018) & $\begin{array}{l}\text { They were born in a world surrounded by smartphones, internet and social media. Therefore, they can use } \\
\text { technology with competence. }\end{array}$ \\
\hline $\begin{array}{l}\text { Haddouche and Salomone } \\
\text { (2018) }\end{array}$ & $\begin{array}{l}\text { They live in a world surrounded by smartphones, video games and the internet. Sending-sharing e-mails, SMS, } \\
\text { likes are an integral part of their daily lives. }\end{array}$ \\
\hline Susanti and Natalia (2018) & $\begin{array}{l}\text { Gen } Z \text { tend to be closer to their friends than family members. They attach importance to social interaction with } \\
\text { friends and have expectations to act independently. }\end{array}$ \\
\hline Francis and Hoefel (2018) & $\begin{array}{l}\text { The main point for Gen } Z \text { is not just to immerse themselves in stereotypes, but to experiment with different ways } \\
\text { of being themselves and to shape their identities over time. The essence of Gen } Z \text { is the idea of expressing } \\
\text { individual identity. Consumption is therefore a means of self-expression, not conforming to any group norms. }\end{array}$ \\
\hline $\begin{array}{l}\text { Taş, Demirdöğmez and } \\
\text { Küçükoğlu (2017) }\end{array}$ & $\begin{array}{l}\text { Gen Z, which uses computers and digital technology intensively, does not spend much time outside and } \\
\text { communicate online. A life without a computer and mobile phone is unthinkable. As a matter of fact, they } \\
\text { haven't experienced a life without technology. Gen Z, who grew up in a period of economic depression in the } \\
\text { world, prefers to act more individually rather than teamwork. }\end{array}$ \\
\hline Samitra and Rozi (2017) & $\begin{array}{l}\text { Gen } Z \text { is a self-evolving creative generation. One of the most important advantages of the Gen } Z \text { is that they } \\
\text { can quickly adapt to technology. However, the environmental sensitivity levels of the Gen } Z \text {, which has } \\
\text { environmental and social awareness, may be relatively lower. Because their life is intertwined with social } \\
\text { media and the level of interaction with the environment (nature) is low. }\end{array}$ \\
\hline $\begin{array}{l}\text { Solmaz, Kara and Kartal } \\
\text { (2017) }\end{array}$ & $\begin{array}{l}\text { Gen } Z \text { can be characterized as confident, environmentally conscious, intelligent, entrepreneurial and open- } \\
\text { minded. }\end{array}$ \\
\hline Lanier (2017) & $\begin{array}{l}\text { Gen Z'ers are pragmatic. Living in a period of global recession provided them to be logical and stable, as well } \\
\text { as focusing more on their careers and paying more attention to safety, security and privacy. }\end{array}$ \\
\hline $\begin{array}{l}\text { Andrea, Gabriella and Tímea } \\
\text { (2016) }\end{array}$ & $\begin{array}{l}\text { Gen } Z \text { is global generation in real terms. High technology is their structural features. Besides, they have grown } \\
\text { up in an uncertain and complex environment that determined their perspective on business, education, and the } \\
\text { world. }\end{array}$ \\
\hline Aydin and Başol (2014) & They are good at creativity, claiming rights, and relationships with different sociological groups. \\
\hline Singh (2014) & $\begin{array}{l}\text { They were born in a period of intense concerns about terrorism and environmental issues. They witnessed the } \\
\text { widespread use of electronic devices, internet and social networking technologies. They are virtually connected } \\
\text { with global life, flexible and tolerant of different cultures. }\end{array}$ \\
\hline
\end{tabular}


Gen $\mathrm{Z}$ is the main dynamic of the near future. One of the most important characteristics of this generation is that they have witnessed many events and changes. The world is no longer the old world and there is a fluctuation from politics to economics and technology (Simangunsong, 2018). This situation increased the sense of safety and led to escapism behaviour (Priporas, Stylos, \& Fotiadis, 2017). As a result, a unique generation that differs with their parents has emerged (Puiu, 2016).

\section{Sustainable Tourism}

As emphasised by McCool (2016a:7), "Underlying notions of sustainability are important human values such as equity, trust, ownership, ethics, empathy and so on. Sustainability is as much about our values as it is about the technology and expertise needed to apply those values..." In the same framework, the most commonly definitions of sustainable tourism is that "tourism that takes full account of its current and future economic, social and environmental impacts, addressing the needs of visitors, the industry, the environment and host communities" (UNEP-UNWTO, 2005:12). As can be understood, the main idea of sustainable tourism is to enhances the equality of and balance the present and future within the context of meeting the needs of today's visitor-host society (UNWTO, 1998).
It should be noted that global life is in a cycle that is difficult to sustain both socio-economically and environmentally. At this point, it is an undeniable reality that tourism with considerable dynamism cannot be dissociated from economic, social and cultural life (Ciolac, et al., 2019). Therefore, it is very difficult to harmonize the principles of sustainable tourism with the realities of the todays' world (Duran, 2011; Postma, Cavagnaro \& Spruyt, 2017; Çalışkan, 2017).

Tourism, rooted in ancient civilizations, is one of the world's most important sectors. Its contribution to the world economy, increases the importance of tourism policies, especially in developing countries. However, it is inevitable that, rapid tourism development will have a negative impact on nature, culture and society. This dual nature of tourism, which is based on the predicted growth and projected damage dilemma, requires strategic approaches (Budeanu, 2005). However, the starting point of sustainable tourism is the negative effects of tourism activities on nature. At this point, it is imperative to balance social and environmental costs, protect natural resources and respect local culture. In addition, the outputs from tourism should create an opportunity for new generations (Escoto, Boza \& Madrigal, 2019). Thus, highlights of sustainable tourism on social, economic and environmental dimensions are summarized in Table 2.

Table 2. Highlights on The Sustainable Tourism

\begin{tabular}{|c|c|}
\hline Author(s) & Highlights of Characterizing Sustainable Tourism \\
\hline Nechad (2019) & $\begin{array}{l}\text { Combining sustainability of natural resources and social and human structures and maintaining of the } \\
\text { development capacities of future generations. }\end{array}$ \\
\hline $\begin{array}{l}\text { Amerta, Sara and Bagiada } \\
\text { (2018) }\end{array}$ & $\begin{array}{l}\text { Reducing overuse of natural sources, maintaining biodiversity, enabling natural sources for future } \\
\text { generations. }\end{array}$ \\
\hline $\operatorname{McCool}(2016 b)$ & Environmentally appropriate, socially acceptable, and economically viable activities. \\
\hline Janusz and Bajdor (2013) & $\begin{array}{l}\text { Balancing use of environmental sources, economic growth, community/social values and economic } \\
\text { benefits of tourism. }\end{array}$ \\
\hline Choi and Sirakaya Turk (2011) & $\begin{array}{l}\text { Managing tourism for community by considering the spectrum of economic, social, cultural, natural, } \\
\text { technological, and political environments. }\end{array}$ \\
\hline $\begin{array}{l}\text { Jamal, Taillon and Dredge } \\
\text { (2011) }\end{array}$ & $\begin{array}{l}\text { Using not only vocational and technical knowledge, but also understanding and addressing ethical and } \\
\text { critical thinking in the process of establishing sustainable tourism. }\end{array}$ \\
\hline Sharpley (2010) & $\begin{array}{l}\text { Sustainable use of sources, development of tourism by considering the physical and socio-cultural } \\
\text { capacities, equitable opportunity to take advantage of tourism. }\end{array}$ \\
\hline Telfer and Sharpley (2008) & $\begin{array}{l}\text { Planned and managing environmental limits; raising awareness through education; monitoring impacts; } \\
\text { involving indigenous people, women and minority groups. }\end{array}$ \\
\hline Lansing and De Vries (2007) & $\begin{array}{l}\text { Minimizing impact on and be proactive about preserving the natural resources (e.g. maintaining water } \\
\text { and air quality, the protection of flora and fauna and their habitat); local participation, the prevention of } \\
\text { profits leaking out of host country or community; mapping of sociocultural effects of tourism development. }\end{array}$ \\
\hline Kasim (2006) & $\begin{array}{l}\text { Creating collective consciousness in all segments of society, such as businesses, policy makers, planners } \\
\text { and NGOs, to prioritize environmental and social issues. }\end{array}$ \\
\hline Sharpley (2000) & Protecting and enhancing the natural, social and cultural sources upon which tourism depends. \\
\hline Welford and Ytterhus (1998) & Development by considering the local economic limits and pattern of social diversity. \\
\hline Brown and Essex (1997) & Long-term social, economic and environmental benefits, while enhancing the its own viability. \\
\hline Aronsson (1994) & Providing a source of income for residents in an area and support the local culture. \\
\hline $\begin{array}{l}\text { Owen, Witt and Gammon } \\
\text { (1993) }\end{array}$ & $\begin{array}{l}\text { Managing and safeguarding of the earth's resources by considering the a number of unprecedented threats } \\
\text { such as population growth, global warming, destruction of the ozone layer, degradation of the } \\
\text { environment, the loss of biological species and habitats, and pollution in all its forms. }\end{array}$ \\
\hline
\end{tabular}


As seen in Table 2, management and protection of sources, equality, viability, and participation are the key factors of sustainability and (balanced) tourism development. In other words sustainable tourism emerged by forging a link between sustainable development ideas and tourism, refers harmony between human activities and the nature (Zamfir \& Corbos, 2015).

\section{Sustainable Tourism and Gen $Z$}

Conservation of the physical and human environment are main factors in the understanding of sustainable tourism (Butler, 1993). Likewise, natural resources, physical environment and social structure are the key variables of balanced economic growth (Swarbrooke, 1999). It should be noted that, the ultimate aim of tourism development is to provide economic and social gains. But sustainability of limited resources and the natural environment are the core principles of this understanding (Liu, 2003). At this point, there is no doubt that, it is necessary to establish a balance between the relevant components (Lane, 1994) and social participation should be ensured for the establishment of inter-generational equality (Hardy, Beeton \& Pearson, 2002). However, conservation of cultural integrity, ecological diversity and vital resources is essential, and a resource management that takes into account economic, social and aesthetic needs is important (Neto, 2003). With the general approach, sustainable tourism should provide economic advantage and social benefit, not degrade the environment, and the goals in this denominator should be valid for both present and future generations (Mcminn, 1997; Hunter, 1997). Hence, respect for nature, culture (Niedziółka, 2014), community participation (Bramwell \& Sharman, 2000) and future generations (Tosun, 2001) are the core factors in sustainable tourism. In this context, Gen Z'ers can be seen as the current, dynamic and basic variable of sustainable tourism. However, the Gen Z, which is the crystal generation of the digital age (Yalçın Kayıkçı \&Kutluk Bozkurt, 2018), are collaborative but less loyal and have to face or solve difficult environmental, social and economic problems (Çetin \& Karalar, 2016). This situation makes the Gen Z, which are practical minded, individualistic, self-directed and in constant communication with their social network (Desai \& Lele, 2017), a sociological reality of sustainable tourism.

\section{Conclusion and Discussion}

It is necessary to consider and evaluate today's world from different dimensions. Each century has different lifestyles and habits in itself. Therefore, it is essential to analyze new life styles (such as Agricultural Society, Industrial Society and Digital/Information Society), which are an economic consequence of social changes (Yıldırımalp \& Güvenç, 2020). At this point, it is important to discuss tourism in terms of social, economy and environment, on the basis of today's generations. As a matter of fact, while the digital age we are in has important effects on different sectors, this reality brings along sociological consequences in the context of the generation concept (Bağçı \& İçöz, 2019).

The effects of the Digital Age have also been reflected in tourism, and so socio-political and economic restructuring has led to the spatial spread and market enlargement of tourism. Ultimately, this development has made the concept of sustainability a global reality (Butler, 1999). In this context, socio-culture, environment, economy, education, community participation and protectionism have been the prominent factors of sustainable tourism (Mowforth \& Munt, 2009). Obviously, the existence of tourism is based on variables such as social and economic factors and is also under the constant pressure of these variables (Buckley, 2012). With a similar discourse, society and consumption become a dilemma of sustainability within the context of economic and social facts (Çalışkan, 2017). Therefore, it would be a constructive approach to interpret the positive and negative features of today's young generation with the principles of sustainable tourism.

As known, sustainable tourism can help reduce inequality (Grilli, et al., 2021), provides continuing of legitimacy of tourism development (Fermani, et al., 2020). Moreover, given that sustainable tourism is becoming a incontrovertible reality and a critical issue for relevant studies (Liu, et al., 2016), a sense of social awareness should be created in the understanding of sustainable tourism. Here, Gen Z'ers' easy access to information, having high perception skills (Seibert, 2021) and a structure that respects values (Çetin \& Karalar, 2016) can be seen as an important opportunity. The individualistic nature of the Gen $\mathrm{Z}$ may cause an ambiguous situation in the perspective of sustainable tourism, but it is thought that their collaborative and collective structures can be functional in the implementation and evaluation processes. It should be especially emphasized that, considering their communication network, use of social media and interaction levels, 
it is seen that the Gen Z'ers have strong and fast perception and interpretation ability. Therefore, Gen Z has an important potential for a sustainable future. In this context, decision makers and practitioners should understand the culture of the Gen Z, analyze and use their dynamism. As a matter of fact, today's young generation who have already pro-sustainability lifestyle. However, getting more support on this issue may contribute to the establishment of a more sustainable lifestyle in general (Yamane \& Kaneko, 2021).

Finally, the difficult socio-political processes experienced by Gen Z have become more rigid with the COVID 19 Pandemic. With the pandemic, which is the depression of all humanity, loss of life has been experienced, new health risks have occurred, everyday routines were disrupted and the concept of "new normal" has emerged (Karakaş, 2020). It is inevitable that such a global threat will affect today's generation. However, there are global constraints in terms of education, socialization and motivation of Gen Z'ers (Tekin, 2020). At this point, more observations and research related to sociopolitical, economic and psychological agenda in question are needed. Therefore, Gen Z'ers' behavioral structures, emotional tendencies and awareness levels of social problems need to be reevaluated within the context of the pandemic

\section{References}

Adıgüzel, O., Batur, H. Z., \& Ekşili, N. (2014). Kuşakların Değişen Yüzü ve Y Kuşaği ile Ortaya Çıkan Yeni Çalışma Tarzı: Mobil Yakalılar. Süleyman Demirel Üniversitesi Sosyal Bilimler Enstitüsü Dergisi, 1(19), 165-182.

Alwin, D. F., \& McCammon, R. J. (2007). Rethinking generations. Research in Human Development, 4(3-4), 219-237.

Amerta, I. M. S., Sara, I. M., \& Bagiada, K. (2018). Sustainable tourism development. International research journal of management. IT and social sciences, 5(2), 248-254.

Anantatmula, V. S., \& Shrivastav, B. (2012). Evolution of project teams for Generation $\mathrm{Y}$ workforce. International Journal of Managing Projects in Business, 5(1), 9-26.

Andereck, K. L., Valentine, K. M., Knopf, R. C., \& Vogt, C. A. (2005). Residents' perceptions of community tourism impacts. Annals of tourism research, $32(4), 1056-1076$.

Andrea, B., Gabriella, H., \& Tímea J. (2016). Y and Z Generations at Workplaces. Journal of Competitiveness 8(3), 90-106.

Ap, J. (1992). Residents' perceptions on tourism impacts. Annals of tourism Research, 19(4), 665-690.
Arı, E. S. (2021). Süper Akıllı Toplum: Toplum 5.0. Dokuz Eylül Üniversitesi Sosyal Bilimler Enstitüsü Dergisi, 23(1), 455-479.

Aronsson, L. (1994). Sustainable tourism systems: The example of sustainable rural tourism in Sweden. Journal of Sustainable Tourism, 2(1-2), 77-92.

Aydın, G. Ç., \& Başol, O. (2014). X ve Y Kuşağı: Çalışmanın Anlamında Bir Değişme Var Mı? Ejovoc (Electronic Journal of Vocational Colleges), 4(4), 1-15.

Bağçı, E., \& İçöz, O. (2019). Z ve Alfa Kuşağı ile Dijitalleşen Turizm. Güncel Turizm Araştırmaları Dergisi, 3(2), 232-256.

Bramwell, B., \& Sharman, A. (2000). Approaches to sustainable tourism planning and community participation: the case of the Hope Valley G. Richards, D. Hall (Eds.), Tourism and sustainable community development, Routledge, London, New York, pp. 17-35.

Brown, G., \& Essex, S. (1997). Sustainable tourism management: lessons from the edge of Australia. Journal of Sustainable Tourism, 5(4), 294-305.

Buckley, R. (2012). Sustainable tourism: Research and reality. Annals of tourism research, 39(2), 528546.

Budeanu, A. (2005). Impacts and responsibilities for sustainable tourism: a tour operator's perspective. Journal of cleaner production, 13(2), 89-97.

Butler, R. W. (1993). Tourism - an evolutionary perspective. In J.G. Nelson, R. Butler and G. Wall (eds) Tourism and Sustainable Development: Monitoring, Planning and Managing. Department of Geography Publication Series Number 37. Waterloo: University of Waterloo, pp. 27-43.

Butler, R. W. (1999). Sustainable tourism: A state-of-theart review. Tourism geographies, 1(1), 7-25.

Chicca, J., \& Shellenbarger, T. (2018). Connecting with Generation Z: Approaches in nursing education. Teaching and Learning in Nursing, 13(3), 180184.

Chillakuri, B. (2020). Understanding Generation Z expectations for effective onboarding. Journal of Organizational Change Management, 33(7), 1277-1296.

Choi, H. C., \& Turk, E. S. (2011). Sustainability indicators for managing community tourism. In M. Budruk, \& R. Phillips (Eds.), Quality-of-Life community indicators for parks, recreation and tourism management (pp. 115-140). New York, NY: Springer.

Ciolac, R., Adamov, T., Iancu, T., Popescu, G., Lile, R., Rujescu, C., \& Marin, D. (2019). Agritourism-A Sustainable development factor for improving the 
'health'of rural settlements. Case study Apuseni mountains area. Sustainability, 11(5), 1467.

Çalışkan, C. (2017). Sürdürülebilir Turizmin Çevre İkilemi: Toplum ve Tüketim. Itobiad: Journal of the Human \& Social Science Researches, 6(2), 1123-1136.

Çetin, C., \& Karalar, S. (2016). X, Y ve Z kuşağ öğrencilerin çok yönlü ve sınırsız kariyer algıları üzerine bir araştırma. Yönetim Bilimleri Dergisi, 14(28), 157-197.

Desai, S. P., \& Lele, V. (2017). Correlating internet, social networks and workplace-a case of generation $\mathrm{Z}$ students. Journal of Commerce and Management Thought, 8(4), 802-815.

Duran, E. (2011). Turizm, Kültür ve Kimlik İlişkisi; Turizmde Toplumsal ve Kültürel Kimliğin Sürdürülebilirliği. İstanbul Ticaret Üniversitesi Sosyal Bilimler Dergisi, 10(19), 291-313.

Escoto, B. E. B., Boza, P. M., \& Madrigal, F. D. (2019). Sustainable tourism: A competitiveness strategy perspective in Baja California. Sustainability, 11(24), 6934 .

Fermani, A., Sergi, M. R., Carrieri, A., Crespi, I., Picconi, L., \& Saggino, A. (2020). Sustainable Tourism and Facilities Preferences: The Sustainable Tourist Stay Scale (STSS) Validation. Sustainability, $12(22), 9767$

Francis, T., \& Hoefel, F. (2018). ‘True Gen’: Generation Z and its implications for companies. McKinsey \& Company,

www.mckinsey.com/industries/consumerpackaged-goods/our-insights/true-gengeneration- $\mathrm{z}^{-}$-and-its-implications-forcompanies (Accessed, 9.04.2021).

Fukuyama, M. (2018). Society 5.0: Aiming for a new human-centered society. Japan Spotlight, 27, 4750 .

Gabrielova, K., \& Buchko, A.A. (2021). Here comes Generation Z: Millennials as managers Business Horizons, https://doi.org/10.1016/j.bushor.2021.02.013.

Garrod, B., \& Fyall, A. (1998). Beyond the Rhetoric of Sustainable Tourism?, Tourism Management, 3(19), 199-212.

Giddings, B., Hopwood, B., \& O'brien, G. (2002). Environment, economy and society: fitting them together into sustainable development. Sustainable development, 10(4), 187-196.

Goverment of Japan. (2016). The 5th Science and Technology Basic Plan, https://www8.cao.go.jp/cstp/english/basic/5thbasi cplan.pdf (Accessed, 9.05.2021).

Grilli, G., Tyllianakis, E., Luisetti, T., Ferrini, S., \& Turner, R. K. (2021). Prospective tourist preferences for sustainable tourism development in Small Island Developing States. Tourism Management, 82, 104178.

Haddouche, H., \& Salomone, C. (2018). Generation Z and the tourist experience: tourist stories and use of social networks. Journal of Tourism Futures, 4(1), 69-79.

Hall, C. M., \& Lew, A. A. (2009). Understanding and managing tourism impacts: An integrated approach. Routledge.

Harayama, Y. (2017). Society 5.0: Aiming for a New Human-centered Society. https://www.hitachi.com/rev/archive/2017/r2017 06/pdf/p08-13_TRENDS.pdf (Accessed, 9.05.2021).

Hardy, A., Beeton, R. J., \& Pearson, L. (2002). Sustainable tourism: An overview of the concept and its position in relation to conceptualisations of tourism. Journal of sustainable tourism, 10(6), 475-496.

Higgins-Desbiolles, F. (2018). Sustainable tourism: Sustaining tourism or something more?. Tourism management perspectives, 25, 157-160.

Hoxha, V., \& Zeqiraj, E. (2020). The impact of Generation $\mathrm{Z}$ in the intention to purchase real estate in Kosovo. Property Management, 38(1), 124.

Hunter, C. (1997). Sustainable tourism as an adaptive paradigm. Annals of tourism research, 24(4), 850867.

Hysa, B., Karasek, A., \& Zdonek, I. (2021). Social media usage by different generations as a tool for sustainable tourism marketing in society 5.0 idea. Sustainability, 13(3), 1018.

İnce, M., \& Bozyiğit, S. (2018). Tüketicilerin Instagram Reklamlarına Karşı Tutumlarının Satın Alma Davranışları Üzerindeki Etkisi: Y ve Z Kuşağı Üzerine Bir Araştırma. Beykoz Akademi Dergisi, 6(2), 39-56.

Jamal, T., Taillon, J., \& Dredge, D. (2011). Sustainable tourism pedagogy and academic-community collaboration: A progressive service-learning approach. Tourism and Hospitality Research, 11(2), 133-147.

Janusz, G. K., \& Bajdor, P. (2013). Towards to sustainable tourism-framework, activities and dimensions. Procedia economics and finance, 6 , 523-529.

Kapecki, T. (2020). Elements of Sustainable Development in the Context of the Environmental and Financial Crisis and the COVID-19 Pandemic. Sustainability, 12(15), 6188. 
Karakaş, M. (2020). Covid-19 salgınının çok boyutlu sosyolojisi ve yeni normal meselesi. Istanbul Üniversitesi Sosyoloji Dergisi, 40(1), 541-573.

Kasim, A. (2006). The need for business environmental and social responsibility in the tourism industry. International journal of hospitality \& tourism administration, $7(1), 1-22$.

Keleş, H. N. (2011). Y kuşağı çalışanlarının motivasyon profillerinin belirlenmesine yönelik bir araştırma. Organizasyon ve Yönetim Bilimleri Dergisi, 3(2), 129-139.

Keskin, İ. (2018). Dijital Dünyanın Sesini Duyabilenler, http://www.irfankeskin.com/wpcontent/uploads/2018/02/Dijital-Dunyanin-SesiDuyabilenler.pdf (Accessed, 09.05.2021).

Klopotan, I., Aleksić, A., \& Vinković, N. (2020). Do business ethics and ethical decision making still matter: Perspective of different generational cohorts. Business Systems Research: International journal of the Society for Advancing Innovation and Research in Economy, 11(1), 3143.

Koltun, P. (2010). Materials and sustainable development. Progress in Natural Science: Materials International, 20, 16-29.

Kupperschmidt, B. R. (2000). Multigenerational employees: strategies for effective management. The Health Care Manager, 19(1), 65-76.

Lane, B. (1994). Sustainable rural tourism strategies: A tool for development and conservation. Journal of sustainable tourism, 2(1-2), 102-111.

Lanier, K. (2017). 5 things HR professionals need to know about Generation Z: thought leaders share their views on the HR profession and its direction for the future. Strategic HR Review 16(6): 288-90.

Lansing, P., \& De Vries, P. (2007). Sustainable tourism: ethical alternative or marketing ploy?. Journal of Business Ethics, 72(1), 77-85.

Liu, C. H., Horng, J. S., Chou, S. F., Chen, Y. C., Lin, Y. C., \& Zhu, Y. Q. (2016). An empirical examination of the form of relationship between sustainable tourism experiences and satisfaction. Asia Pacific Journal of Tourism Research, 21(7), 717-740.

Liu, Z. (2003). Sustainable tourism development: A critique. Journal of sustainable tourism, 11(6), 459-475.

Lordkipanidze, M., Brezet, H., \& Backman, M. (2005). The entrepreneurship factor in sustainable tourism development. Journal of cleaner production, 13(8), 787-798.

McCool, S. (2016b). The changing meanings of sustainable tourism. In: S.F. McCool \& K. Bosak (Eds.) Reframing sustainable tourism,
Environmental challenges and solutions, Vol 2, pp 13-32. Dordrecht: Springer.

McCool, S. F. (2016a). Sustainable tourism in an emerging world of complexity and turbulence. In S. F. McCool \& K. Bosak (Eds.), Reframing sustainable tourism, Environmental challenges and solutions, Vol 2, pp. 3-11. Dordrecht: Springer.

McMinn, S. (1997). The challenge of sustainable tourism. Environmentalist, 17(2), 135-141.

Mowforth, M., \& Munt, L. (2009). Tourism and sustainability: Development, globalization and new tourism in the Third World (3rd ed.). London and New York: Routledge.

Nechad, A. (2019). Situated Sustainable Tourism: An Alternative for Emerging Countries. Journal of Economic and Social Development, 6(1), 78-86.

Neto, F. (2003). A new approach to sustainable tourism development: Moving beyond environmental protection. In Natural resources forum. Oxford, UK: Blackwell Publishing Ltd, pp. 212-222.

Niedziółka, I. (2014). Sustainable tourism development. Regional formation and development studies, $8(3), 157-166$

Owen, R. E., Witt, S. F., \& Gammon, S. (1993). Sustainable tourism development in Wales: From theory to practice. Tourism Management, 14(6), 463-474.

Özel, M. (2007). Çağımız Çevre sorunlarının düşünsel temelleri üzerine bir yaklaşım. Gazi Üniversitesi Íktisadi ve Ídari Bilimler Fakültesi Dergisi, 9(1), 207-226.

Pereira, A. G., Lima, T. M., \& Charrua-Santos, F. (2020). Industry 4.0 and Society 5.0: opportunities and threats. International Journal of Recent Technology and Engineering, 8(5), 3305-3308.

Postma, A., Cavagnaro, E., \& Spruyt, E. (2017). Sustainable tourism 2040. Journal of Tourism Futures. 3(1), 13-22.

Priporas, C. V., Stylos, N., \& Fotiadis, A. K. (2017). Generation Z consumers' expectations of interactions in smart retailing: A future agenda. Computers in Human Behavior, 77, 374-381.

Priporas, C. V., Stylos, N., \& Kamenidou, I. E. (2020). City image, city brand personality and generation $Z$ residents' life satisfaction under economic crisis: Predictors of city-related social media engagement. Journal of Business Research, 119, 453-463.

Puiu, S. (2016). Generation Z-a new type of consumers. Revista tinerilor economişti, 27, 67-78.

Robinson, V. M., \& Schänzel, H. A. (2019). A tourism inflex: Generation Z travel experiences. Journal of Tourism Futures, 5(2), 127-141. 
Roblek, V., Meško, M., Bach, M. P., Thorpe, O., \& Šprajc, P. (2020). The interaction between internet, sustainable development, and emergence of society 5.0. Data, 5(3), 80 .

Rosenau, J. (1995). Governance in the Twenty-First Century. Global Governance, 1(1), 13-43.

Sakdiyakorn, M., Golubovskaya, M., \& Solnet, D. (2021). Understanding Generation Z through collective consciousness: Impacts for hospitality work and employment. International Journal of Hospitality Management, 94, 102822.

Samitra, D., \& Rozi, Z. F. (2017). 26. Conservation Character of Biology Learning for Z Generation. Conference Proceeding BICSE, pp.168-171.

Seibert, S. A. (2021). Problem-based learning: a strategy to foster generation Z's critical thinking and perseverance. Teaching and Learning in Nursing, 16(1), 85-88.

Sharpley, R. (2000). Tourism and sustainable development: Exploring the theoretical divide. Journal of Sustainable tourism, 8(1), 1-19.

Sharpley, R. (2010). The myth of sustainable tourism. CSD Working Papers Series 2009/2010 - No. 4. CSD Center for Sustainable Development.

Simangunsong, E. (2018). Generation-z buying behaviour in Indonesia: Opportunities for retail businesses. MIX: Jurnal Ilmiah Manajemen, $8(2)$, $243-253$.

Singh, A. (2014). Challenges and issues of generation $\mathrm{Z}$. IOSR Journal of Business and Management, 16(7), 59-63.

Solmaz, B., Kara, N., \& Kartal, Ö. (2017). The Importance of Graphology In Determining of The Managerial Qualities of The Future Women Leaders Within The Z Generation: A Research Done On International Business Management Students of Coventry University. European Journal of Interdisciplinary Studies, 3(3), 98-102.

Subawa, N. S., Widhiasthini, N. W., Pika, P. A. T. P., Suryawati, P. I., \& Astawa, I. N. D. (2020). Generation Z Behavior And Low Price Products In The Era Of Disruption. International Journal of Social Sciences and Management Review, 3(3), 112 .

Susanti, A., \& Natalia, T. W. (2018). Public space strategic planning based on $\mathrm{Z}$ generation preferences. In IOP Conference Series: Materials Science and Engineering 407(1), 1-6.

Swarbrooke, J. (1999). Sustainable tourism management. Oxford: CABI.

Taş, H. Y., Demirdöğmez, M., \& Küçükoğlu, M. (2017). Geleceğimiz olan $\mathrm{Z}$ kuşağının çalışma hayatına muhtemel etkileri. OPUS Uluslararası Toplum Araştırmaları Dergisi, 7(13), 1031-1048.
Tekin, E. (2020). COVID-19 kaygisının motivasyon üzerindeki etkisi: Z Kuşağı üzerine bir araştırma. Turkish Studies, 15(4), 1129-1145.

Telfer, D., \& Sharpley, R. (2008). Tourism and Development in the Developing World. London: Routledge.

Tosun, C. (2001). Challenges of sustainable tourism development in the developing world: the case of Turkey. Tourism management, 22(3), 289-303.

United Nations Environment Programme/World Tourism Organization. (2005). Making Tourism More Sustainable: A Guide for Policy Makers, UNEP/UNWTO, Paris/Madrid.

Weaver, D. B. (2006). Sustainable tourism: Theory and practice. Routledge.

Welford, R., \& Ytterhus, B. (1998). Conditions for the transformation of eco-tourism into sustainable tourism. European Environment, 8(6), 193-201.

World Commission on Environment and Development (WCED). (1987). Our Common Future. Oxford: Oxford University Press.

World Tourism Organization (UNWTO). (1998). Guide for local authorities on developing sustainable tourism. Madrid: World Tourism Organization.

Yalçın Kayıkçı, M., \& Kutluk Bozkurt, A. (2018). Dijital çağda $Z$ ve Alpha kuşağı, yapay zekâ uygulamaları ve turizme yansimaları. Sosyal Bilimler Metinleri, 1, 54-64.

Yamane, T., \& Kaneko, S. (2021). Is the younger generation a driving force toward achieving the sustainable development goals? Survey experiments. Journal of Cleaner Production, 292, 125932.

Yıldırımalp, S., \& Güvenç, D. (2020), Z Kuşağının Çalışma Ortamı Beklentilerine İlişkin Bir Araştırma. Düzce Üniversitesi Sosyal Bilimler Enstitüsü Dergisi, 10(1), 57-76.

Zamfir, A., \& Corbos, R. A. (2015). Towards sustainable tourism development in urban areas: Case study on Bucharest as tourist destination. Sustainability, 7(9), 12709-12722. 


\title{
INFO PAGE
}

\section{Sustainable tourism: Gen Z?}

\begin{abstract}
Tourism is a system that has social, environmental and economic impacts on a global scale. These impacts, which seem as a chronic problem especially in the balance of environment and economy, need to be evaluated from different perspectives. The concept "sustainable tourism" is an approach for overcoming problems associated with undesirable impacts. Economic gain, resource conservation and inter-and intra-generational equality are the core factors of this approach. Therefore, it is important to reinterpret it in terms of way to today's generation. This generation called Generation Z (Gen Z), have quite different characteristics from previous generations. As natives of the digital world Gen Z'ers, born and growing in a period of economic crises, wars and environmental problems. This innovative generation has a strong communication network, uses technology extensively and easily accesses information. Therefore, it is a significant subject of investigation for the applicability of the concept of sustainable tourism. In this study, the diverging and adaptive aspects of sustainable tourism and Gen Z are examined and various inferences have been made in the context of today's world.
\end{abstract}

Keywords: Tourism, Sustainable Tourism, Gen Z

\section{Authors}

Author statement: Author(s) declare(s) that All procedures performed in studies involving human participants were in accordance with the ethical standards of the institutional and/or national research committee and with the 1964 Helsinki declaration and its later amendments or comparable ethical standards.

This paper does not required ethics committee report Justification: The methodology of this study does not require an ethics committee report. 